\title{
Hydrological Behavior of an Infiltration-Induced Landslide in Colorado, USA
}

\author{
Alexandra Wayllace $\mathbb{D}^{1},{ }^{1}$ Barbara Thunder, ${ }^{2}$ Ning Lu, ${ }^{1}$ Aziz Khan, ${ }^{3}$ and Jonathan W. Godt $\mathbb{D}^{4}$ \\ ${ }^{1}$ Department of Civil and Environmental Engineering, Colorado School of Mines, Golden, CO 80401, USA \\ ${ }^{2}$ Hart Crowser Inc., Seattle, WA 98121, USA \\ ${ }^{3}$ Colorado Department of Transportation Research Branch, Denver, CO 80222, USA \\ ${ }^{4}$ Landslide Hazards Program, U.S. Geological Survey, Denver, CO 80225, USA
}

Correspondence should be addressed to Alexandra Wayllace; awayllac@mines.edu

Received 26 January 2019; Revised 22 March 2019; Accepted 26 March 2019; Published 3 June 2019

Guest Editor: Roberto Valentino

Copyright (c) 2019 Alexandra Wayllace et al. This is an open access article distributed under the Creative Commons Attribution License, which permits unrestricted use, distribution, and reproduction in any medium, provided the original work is properly cited.

\begin{abstract}
Infiltration-induced landslides are common in mountainous and hilly areas of the world. When they occur near transportation corridors, they can impact public safety, impede transport of goods and people, and damage transportation infrastructure. This work presents a study of the hydrological behavior and its effects on the stability of an active landslide located on an embankment along Interstate-70 west of the Eisenhower Tunnel in central Colorado, USA. Groundwater dynamics were monitored for three years; two piezometers were installed near the head of the slide and one piezometer was placed near the toe. The hydrological observations at this site are unusual in that water table positions beneath the westbound shoulder of the highway (upslope) varied twice as much as water table positions beneath the eastbound shoulder (downslope), only $30 \mathrm{~m}$ distant horizontally. To better understand the factors controlling these observed differences, observations of the stratigraphy and the geomorphology of the watershed beyond the landslide body were incorporated into a conceptual model tested using numerical simulations of two-dimensional, variably saturated groundwater flow. Results from the numerical simulations calibrated against field measurements and a seasonally varying stability analysis of the site show that the large observed differences in the water table positions over the short horizontal distance are likely due to a combination of (1) the large size of the watershed that allows a significant amount of infiltration of snowmelt into the hillslope, (2) the contrast of hydrological properties of soils in the watershed, and (3) the changes in steepness of the dip of the bedrock below the slide. These three factors control the direction, speed, and amount of groundwater flow traveling through the slope. It is also shown that the seasonal hydrology of the site is a key factor in the stability of the slope, where most of the observed displacement occurs during the early summer season. Variations in the water table level within a year resulting from low snow years compared to variations from high snow years can be as much as $100 \%$. Finally, it is important to consider the large contributing area of the watershed when evaluating the hillslope hydrologic conditions and remediation options.
\end{abstract}

\section{Introduction}

Infiltration-induced landslides are geological hazards that affect millions of people each year through property damage, remediation costs, and fatalities. Traditional slope stability analyses focus mostly on the mechanical behavior of the slope materials and typically use limiting equilibrium methods to calculate factors of safety. A number of studies have examined infiltration-induced landslides by combining analyses of the hydrological behavior of hillslopes with assessments of slope stability over large areas (e.g., [1-5]); although most of these studies recognize the critical importance of changing water movement and pressure transmission through unsaturated soil, they neglect the effect of the variably saturated hydrological behavior on effective stress and therefore on the soil strength. When water infiltrates into hillslopes, the water content in the hillslope and the water table (or phreatic surface) level vary accordingly. As 
a consequence, matric suction, suction stress, total unit weight, and effective stress change throughout the hillslope, and thus, the stability of the slope is affected. Recently, several studies have combined hydromechanical process models with slope stability analyses to examine these consequences (e.g., [6-10]). However, accurate forewarning of landslide initiation remains a challenge and more information on specific case studies is valuable.

We describe a case study of an active landslide in Summit County, Colorado, along Interstate 70 (I-70) west of the Eisenhower/Johnson Memorial Tunnels (Figure 1). This section of highway is located near the continental divide surrounded by very steep terrain and is heavily traveled with an average daily traffic greater than 20,000 vehicles per day. Access to the landslide site with heavy equipment is limited, and the cost to permanently remedy the landslide situation is estimated to exceed $\$ 10$ million; such a remedial fix would also require closing the highway for an extended period, which is not practical. Paving records indicate that the road surface has been displaced by more than $0.6 \mathrm{~m}$ in the previous two decades and repaired with as many as five pavement overlays a year to maintain a level road surface. Because of the importance of this part of I-70 to commercial and other travel, several efforts to obtain more site information and reduce pavement settlement have been undertaken over the years [9, 11]. In 2010, a systematic effort was initiated to obtain information on the landslide and assess the factors controlling its stability using a conceptual model of seasonally variably hydrology and hydromechanical framework of analysis [9]. As part of this effort, three piezometers and two inclinometers were installed to monitor groundwater fluctuations and deformation, respectively. The observations obtained from these instruments identified highly variable seasonal groundwater table fluctuations on the downstream side of the highway ( 9 to $12 \mathrm{~m}$ ) whereas $30 \mathrm{~m}$ across the highway the groundwater table fluctuates seasonally only 4 to $5 \mathrm{~m}$. Because changes in slope stability over seasonal timescales are driven by hydrologic variations, development of costeffective mitigation strategies requires understanding hydrological behavior over a range of infiltration conditions. This work provides a conceptual model based on the morphology and stratigraphy of the site, the atmospheric conditions, and the main physical mechanisms in the hillslope, supported by field observations of displacement and groundwater variations. A series of numerical simulations based on the conceptual model and calibrated with field data are then used to assess slope stability.

\section{Site Description and Instrumentation}

The landslide is located on I-70 between mileposts 212.0 and 212.1, on the southern facing slope of the Williams Fork Mountains at 3,255 $\mathrm{m}$ above sea level in Summit County, Colorado (Figure 1). The slide area is approximately $175 \mathrm{~m}$ wide and $120 \mathrm{~m}$ long and mostly located south of I-70 where the highway embankment slopes about $31^{\circ}$. The underlying bedrock is predominantly composed of Proterozoic-age metasedimentary gneiss, schist, and pegmatite with intrusive granite bands; morainal deposits can be found on the surface
[12]. The bedrock is weathered up to $12 \mathrm{~m}$ thick in a saprolite layer, which is typically covered by 1 to $4 \mathrm{~m}$ thick colluvial deposits along valley walls. Presently, much of the area is forested although the bedrock is exposed at the surface in the steepest slope sections and along the cut slopes just north of I-70.

The stratigraphy of the site is a result of disturbance related to the construction of I-70 and the boring of the Eisenhower/Johnson Memorial Tunnels in the late 1960s. Sections of colluvium and layers of highly fractured rock were excavated, and tunnel cuttings were used as fill to construct the embankment for the road surface [13]. During the excavation process, multiple landslides were triggered on the slopes immediately north of I-70. The first slope movement at the study site was observed in 1973; since then, movements have been recorded nearly every year.

A series of subsurface investigations have been performed to assess groundwater and stability conditions at the site. In 1996, six boreholes were advanced and three inclinometers were installed by Kumar Associates; four additional boreholes were advanced in 2011 and 2015. During these later investigations, undisturbed material specimens were obtained and tested in the laboratory for hydrological and mechanical properties [14]. These investigations informed the development of a stratigraphic profile of the landslide site and the contributing watershed (Figure 2). On the slope north of I-70, very thin colluvial deposits less than $0.9 \mathrm{~m}$ thick at the surface are followed by a highly fractured rock layer extending to $12.2 \mathrm{~m}$ depth, below which more competent gneiss bedrock is present. The highly fractured layer consists of pebble to small boulder size black gneiss and some granite with chaotic fracturing in all directions. Most fractures are clean, but traces of yellowish clay are present on some fracture surfaces. In the highway portion, asphalt pavement is $0.076 \mathrm{~m}$ thick along the westbound shoulder but up to $0.76 \mathrm{~m}$ thick in the eastbound shoulder. Under the pavement, the highway embankment fill extends down to depths of $8.5 \mathrm{~m}$ and $9.8 \mathrm{~m}$ below ground surface (bgs) in the westbound and eastbound shoulders, respectively. This layer is composed mostly of tunnel cuttings and is a mix of gravel and scattered boulders in a brown, clayey sand matrix, with the presence of some organic material. Prior reports on the area refer to this layer as "tunnel muck." The highway embankment fill is underlain by a 0.9 to $1.5 \mathrm{~m}$ thick layer of highly decomposed black and grey gneiss cobbles 0.1 to $0.15 \mathrm{~m}$ in size with slickensided, clay-filled joints. Clay deposits 0.3 to $0.6 \mathrm{~m}$ thick are present in this layer beneath the eastbound shoulder, while much thinner clay layers are observed beneath the westbound shoulder. Below the decomposed gneiss, the bedrock is present at $12.2 \mathrm{~m}$ to $14.3 \mathrm{~m}$ bgs on the westbound shoulder and $23.7 \mathrm{~m}$ to $25.3 \mathrm{~m}$ bgs on the eastbound shoulder. We note that the dip of the bedrock surface is less steep beneath I-70 than it is upslope; the change in dip may be a natural bench in the bedrock slope or may have been excavated or blasted to accommodate the roadway. Near the toe of the slide, there are native colluvial and alluvial soils at the surface up to $4 \mathrm{~m}$ deep underlain by 0.9 to $1.2 \mathrm{~m}$ of moderately weathered black gneiss bedrock. Competent gneiss bedrock is encountered at $5.2 \mathrm{~m}$ bgs. 


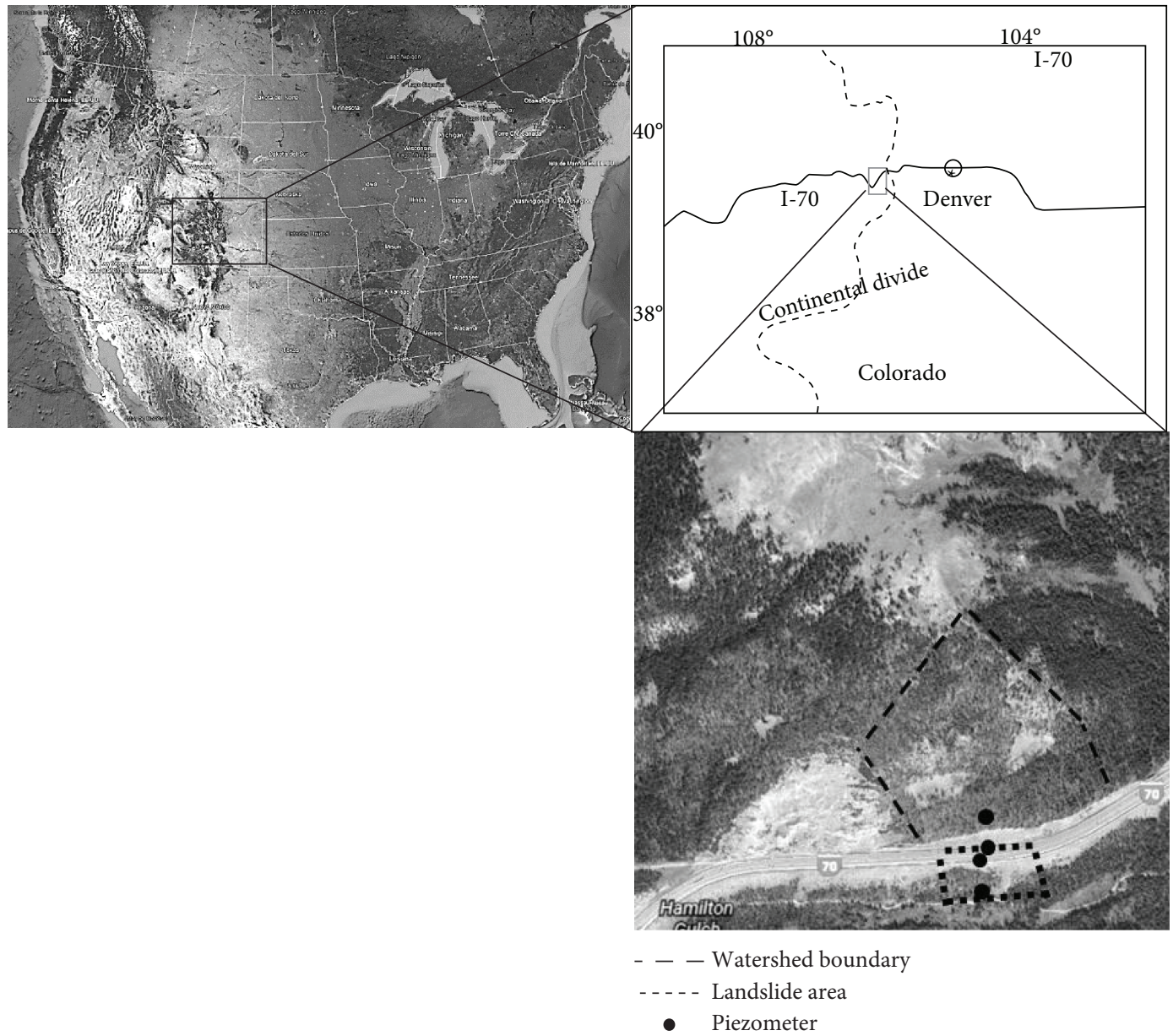

FIGURE 1: Site location with plan view of estimated watershed area, landslide area, and location of piezometers. Images obtained from Google Earth.

Undisturbed samples obtained from the boreholes advanced in 2011 and 2015 were tested to obtain hydrological and strength soil properties. The soil water retention curve (SWRC) and the hydraulic conductivity function (HCF) of two samples of the colluvium and the tunnel fill were measured in the laboratory using the Transient Water Retention and Imbibition Method [15] and modeled with the van Genuchten [16] and Mualem [17] models to obtain the residual moisture content $\theta_{\mathrm{r}}$, the saturated moisture content $\theta_{s}$, and the van Genuchten parameters $\alpha$ and $n$. Direct shear tests of two samples at in situ moisture content were performed to obtain the effective cohesion and friction angle $c^{\prime}$ and $\phi^{\prime}$ of the colluvium and the fill. In addition, three tension infiltrometer tests using a minidisk device from Meter Group (Any use of trade or firm names is for informational purposes only and does not imply endorsement by the U.S. Government.) were performed on the colluvium near the toe of the landslide to establish a range of in situ hydraulic conductivity while a slug test in the borehole north of I-70 provided an estimate of the saturated hydraulic conductivity $\left(k_{s}\right)$ of the highly fractured gneiss. These values are reported in Table 1.

In 2009 and 2011, inclinometers were installed in the westbound shoulder, in the eastbound shoulder, and near the toe of the slide. From the inclinometer readings and field observation, the upslope part of the failure surface of the landslide likely daylights near the westbound shoulder of I-70 and runs along the contact between the decomposed gneiss and more competent bedrock [9]. Figure 3 is an example of inclinometer readings on the westbound and eastbound shoulders taken since 2012; the failure surface on the eastbound is at about $28 \mathrm{~m}$ bgs. Little horizontal displacement is measured at the westbound shoulder at the inclinometer location, indicating that the borehole does not intersect the failure surface. Inclinometer readings taken in 2008-2009 and displacement measured versus elapsed time are reported in $\mathrm{Lu}$ et al. [9].

In 2011 and 2012, three Geokon 4500S ${ }^{1}$ vibrating-wire piezometers were installed to record groundwater table variations every 30 minutes. These sensors are located in the westbound shoulder at $17.37 \mathrm{~m}$ bgs (P1), in the eastbound shoulder at $33.53 \mathrm{~m}$ bgs (P3), and near the toe of the slide at $9.02 \mathrm{~m}$ bgs (P2) (Figure 2). All three piezometers were calibrated in the laboratory according to the manufacturer's instructions and installed in the field using bentonite as local hydraulic seal. The piezometer data obtained from 2011 to 2015 along with precipitation data is provided in Figure 4 and shows the seasonal variation of the water table positions 


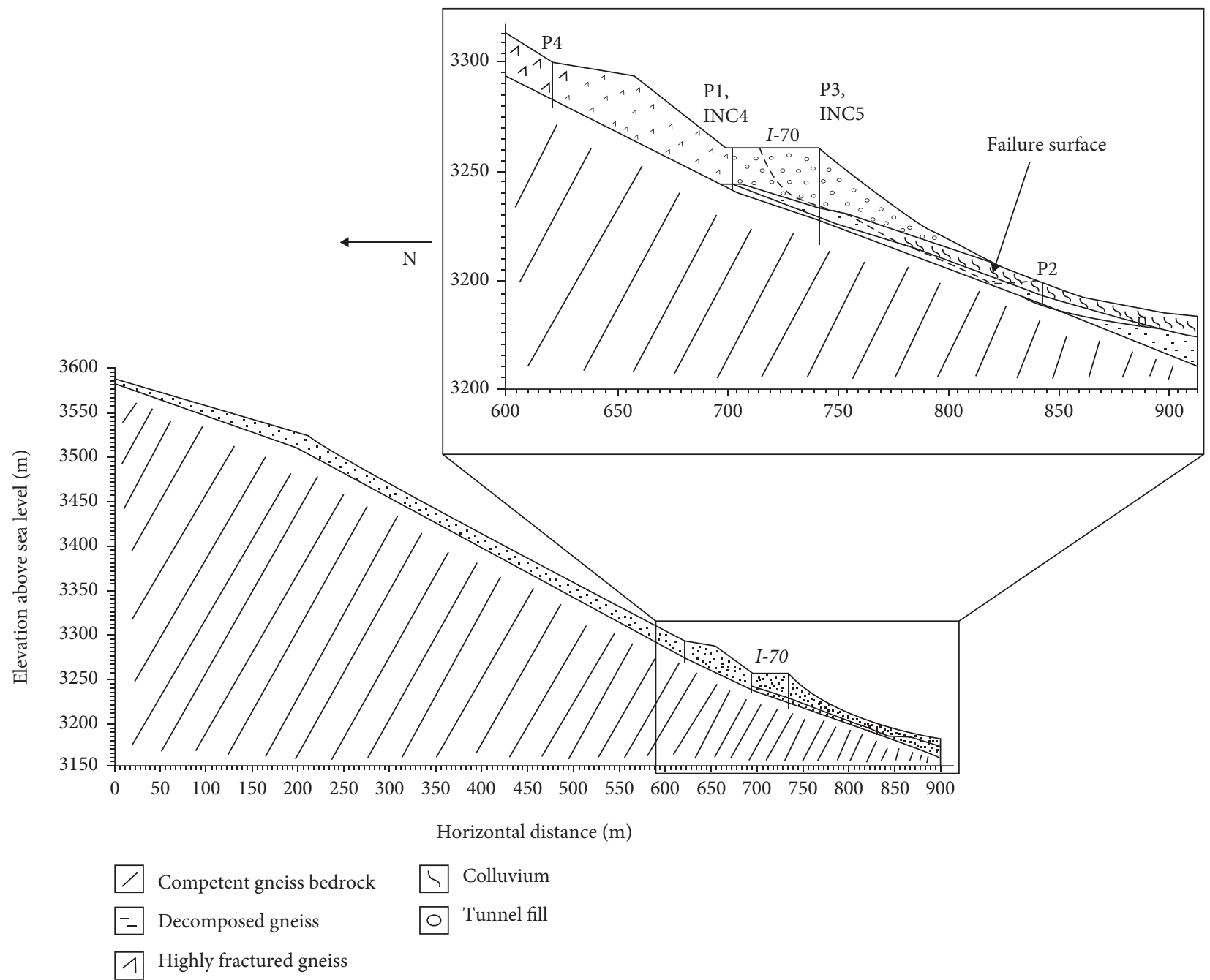

Figure 2: Geologic cross section of the study site.

TABLe 1: Material properties of soil layers.

\begin{tabular}{|c|c|c|c|c|c|c|c|c|}
\hline \multirow{3}{*}{ Material } & \multirow{3}{*}{$\begin{array}{l}\text { Residual moist. } \\
\text { cont. } \theta_{\mathrm{r}}\end{array}$} & \multicolumn{3}{|c|}{ Hydrological properties } & \multicolumn{4}{|c|}{ Strength properties } \\
\hline & & \multirow[t]{2}{*}{$\begin{array}{l}\text { Saturated moist. } \\
\text { cont. } \theta_{s}\end{array}$} & \multicolumn{2}{|c|}{$\begin{array}{c}\text { Van } \\
\text { Genuchten } \\
\text { parameters }\end{array}$} & \multirow{2}{*}{$\begin{array}{l}\text { Sat. Hyd. } \\
\text { conductivity } \\
k_{s}(\mathrm{~m} / \text { day })\end{array}$} & \multirow{2}{*}{$\begin{array}{l}\text { Effective } \\
\text { cohesion } \\
c^{\prime}(\mathrm{kPa})\end{array}$} & \multirow[t]{2}{*}{$\begin{array}{l}\text { Effective friction } \\
\text { angle } \phi^{\prime} \text { (deg) }\end{array}$} & \multirow[t]{2}{*}{$\begin{array}{l}\text { Unit weight } \\
\gamma\left(\mathrm{kN} / \mathrm{m}^{3}\right)\end{array}$} \\
\hline & & & $\alpha\left(\mathrm{m}^{-1}\right)$ & $n$ & & & & \\
\hline Pavement & & & & & & 0 & 32 & 25 \\
\hline Bedrock & $0.06^{*}$ & $0.34^{*}$ & $1.374^{*}$ & $1.72^{*}$ & 0.001 & 95 & 34 & 23 \\
\hline $\begin{array}{l}\text { Decomposed } \\
\text { gneiss }\end{array}$ & $0.065^{*}$ & $0.41^{*}$ & $7.5^{*}$ & $1.89^{*}$ & $1.06^{*}$ & 1 & 23 & 21 \\
\hline Highly fract. gneiss & $0.06^{*}$ & 0.34 & $1.374^{*}$ & $1.72^{*}$ & 40 & 1 & 35 & 22 \\
\hline Colluvium & 0.08 & 0.33 & 2.35 & 2.12 & 6 & 0 & 34 & 20 \\
\hline Tunnel fill & 0.08 & 0.33 & 2.35 & 2.12 & 0.5 & 0 & 30 & 21 \\
\hline
\end{tabular}

*Parameter obtained through numerical model calibration.

at the three locations. Depth to water table below ground surface was calculated by subtracting the measured pressure heads from the location of the sensor. Piezometer P1 located on the westbound shoulder shows a large and rapid response to infiltration each spring when the water table rises 9 to $12 \mathrm{~m}$ in a period of 3 to 4 weeks; however, only $30 \mathrm{~m}$ across the highway, P3 located on the eastbound shoulder shows water table changes of only 4 to $5 \mathrm{~m}$. These observations prompted 


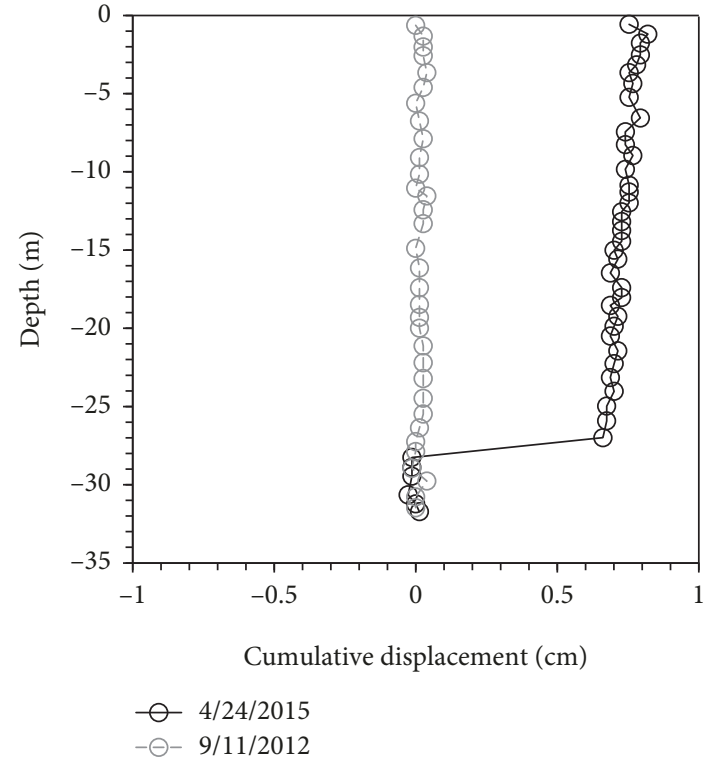

(a)

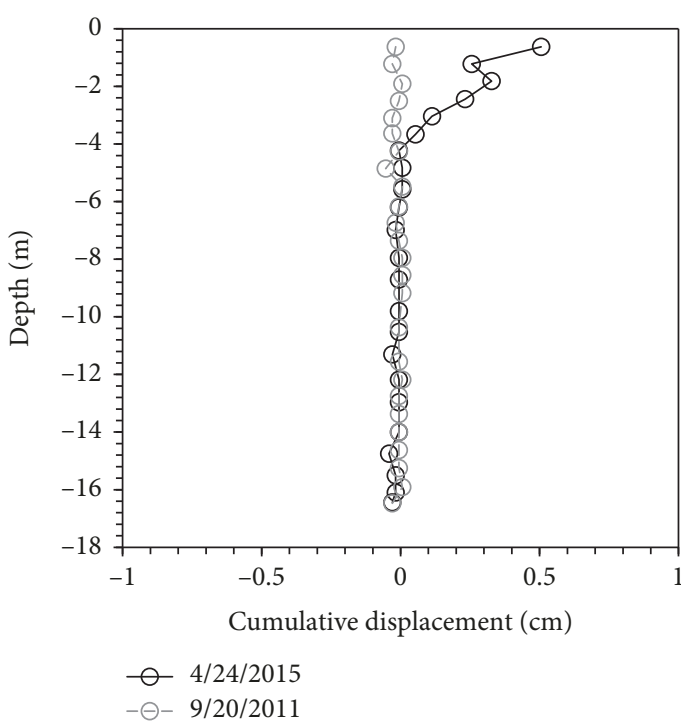

(b)

FIGURE 3: Example of inclinometer data from 2011-2015: (a) INC4 along the westbound shoulder and (b) INC5 along the eastbound shoulder (CDOT, 2015).

the consideration of the larger watershed in the hydrological analysis. Piezometer P2 is located near Straight Creek at the base of the valley, which controls the water table response to some degree and reduces the magnitude of response ( 1 to $2 \mathrm{~m})$ in this location.

Precipitation data are obtained from a National Resources Conservation Service (NRCS) SNOTEL station at Grizzly Peak, located approximately $14 \mathrm{~km}$ southwest of the landslide site. Snowpack information is reported in terms of snow water equivalents (SWE), which represents the total height of a water column the snowpack would be reduced to if melted. Precipitation data include both snowfall and rainfall in the area. Because no long-term measurement of snowpack and rainfall is available for the watershed above the landslide, we instead rely on the Grizzly Peak SNOTEL data for daily atmospheric conditions. The Grizzly Peak station is located about $100 \mathrm{~m}$ higher in elevation in similar terrain on the same side of the continental divide with respect to the landslide site. However, the Grizzly Peak station is in a more heavily forested location. Less tree-cover and the highway corridor lead to greater solar and wind exposure at the landslide site, which presumably leads to an earlier and more rapid melting of the snowpack at the landslide site compared to Grizzly Peak.

\section{Conceptual Hydromechanical Model}

The following conceptual model is proposed based on the field characterization, measured groundwater table variations, and anecdotal reports of slide movement from personnel from the Colorado Department of Transportation (CDOT). It was evident that accurate analysis of the slope stability conditions required accounting for the larger watershed that contributes to the landslide site (Figure 1).
The material variations in the complex disturbed stratigraphy beneath the highway would also need to be considered in any conceptual model. The seasonal variation in infiltration and water table fluctuations can be described by four stages that generally coincide with the annual seasons. Schematic diagrams of the site profile at these four stages are provided in Figure 5 and an example of groundwater table variations at the piezometer locations is given in Figure 6.

Stage I. Winter: in December through the end of February, the water table is at its deepest position below the ground surface with minimal fluctuations. In general, the water table closely follows the contact between the competent bedrock and the weathered gneiss and is below the failure surface of the landslide. Typically, during this period, temperatures are below freezing, snow accumulates in the watershed, and there is negligible infiltration or evaporation. Depending on the year, snow depth can vary from $0.8 \mathrm{~m}$ to as much as $2.9 \mathrm{~m}$ with snow water equivalent values of $0.3 \mathrm{~m}$ to $0.8 \mathrm{~m}$. Throughout this season and as a part of road maintenance, the Colorado Department of Transportation plows snow and packs it onto the westbound shoulder. The embankment is at its most stable condition and minimum displacements occur (Figure 5(a)).

Stage II. Early spring: with the warming temperatures in the early spring, the snowpack starts to melt. Due to the low moisture content of the soils near the surface, the hydraulic conductivity is relatively low, and meltwater enters the hillslope perpendicular to the slope surface [9]. In general, very little change in the groundwater level occurs during this stage, indicating that most of the infiltration does not yet reach the saturated zone. However, a small rise in the water 


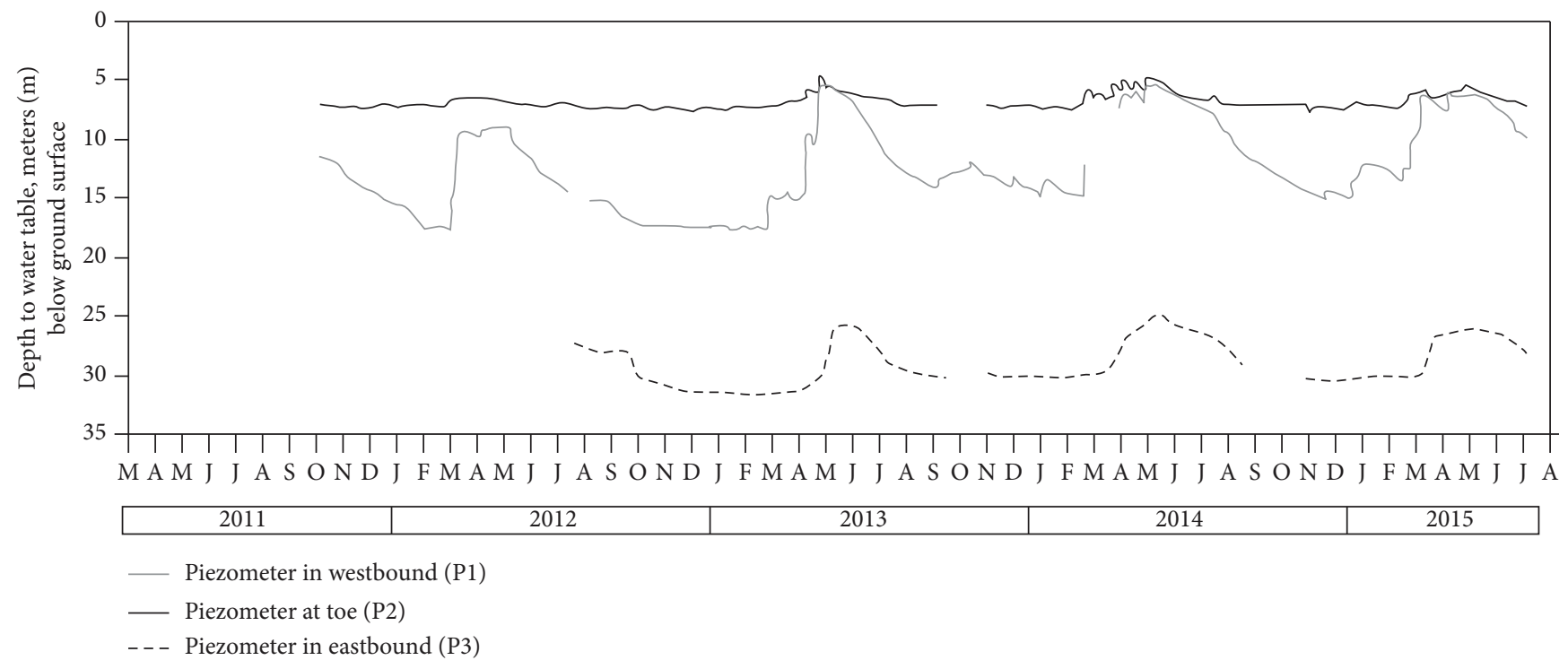

(a)

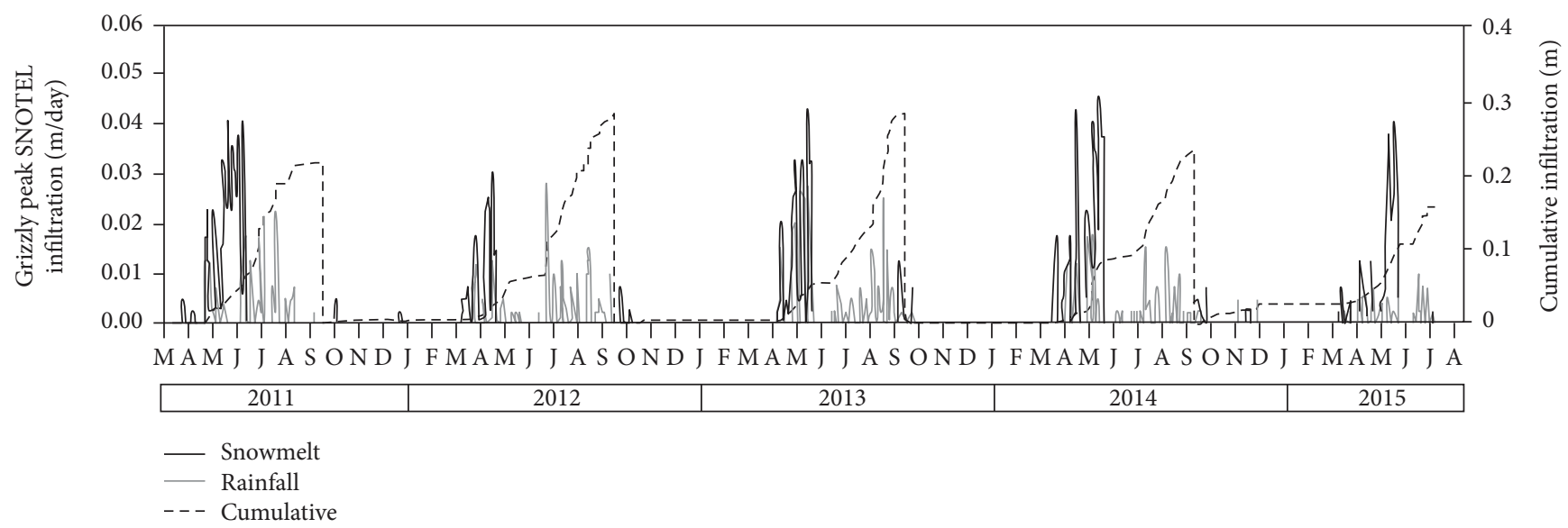

(b)

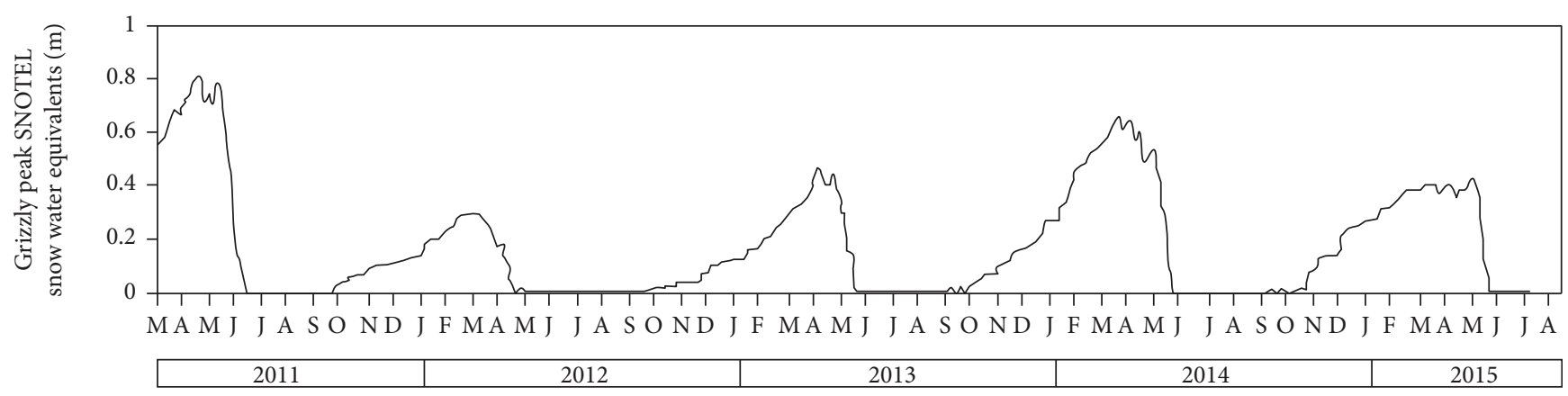

(c)

Figure 4: (a) Piezometer data, (b) infiltration data from Grizzly Peak, and (c) snow water equivalent data from Grizzly Peak.

table below the westbound shoulder occurs, likely due to the packed plowed snow melting along the shoulder. No water infiltrates through the highway surface because the snowfall is plowed off the road and the asphalt pavement is relatively impermeable. Since the water table stays mostly below the failure surface, minimum displacements occur (Figure 5(b)).
Stage III. Late spring and early summer: in April and May, snowmelt and occasional rainfall continue to infiltrate into the hillslope, now flowing faster through soils with greater moisture contents and therefore higher hydraulic conductivities. When the wetting front reaches the saturated zone near the bedrock boundary, the large contrast between the hydraulic conductivities of the highly fractured gneiss and 


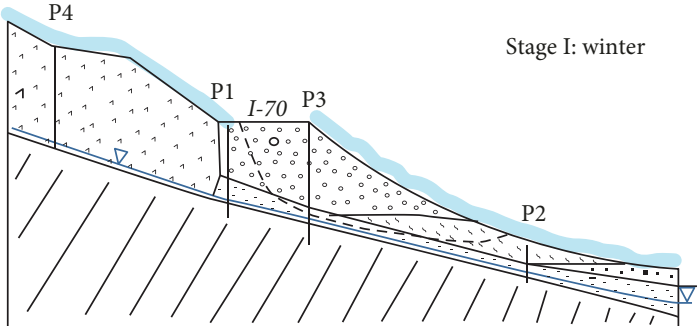

(a)

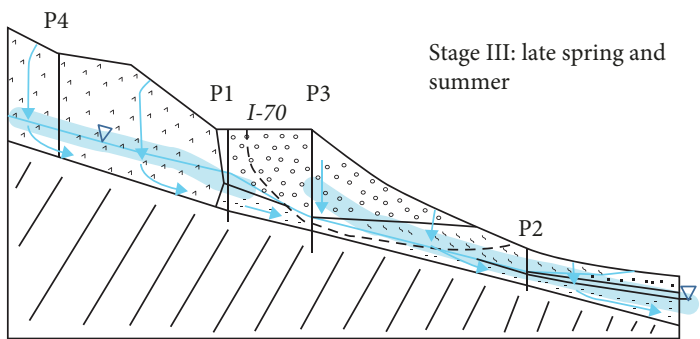

(c)

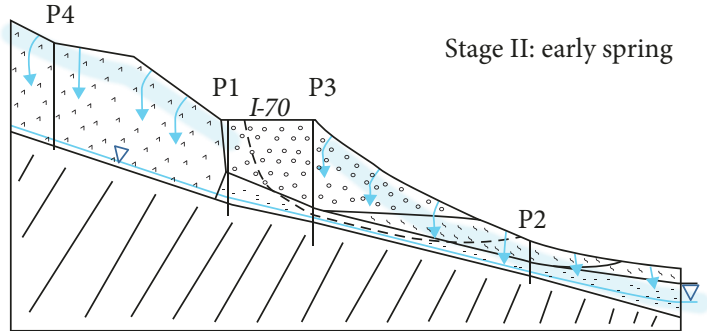

(b)

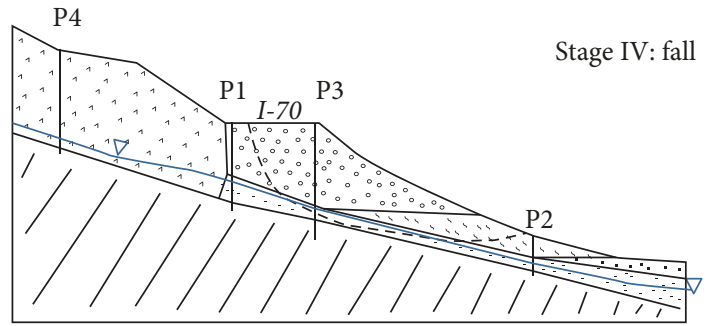

(d)

FIGURE 5: Conceptual model diagram. (a) Stage I (winter): snow accumulates, water table at its deepest position. (b) Stage II (early spring): snow starts melting, water table only rises slightly near westbound shoulder. (c) Stage III (late spring and summer): snow melts, water table level rises, and the landslide is active. (d) Stage IV (fall): water table drains.

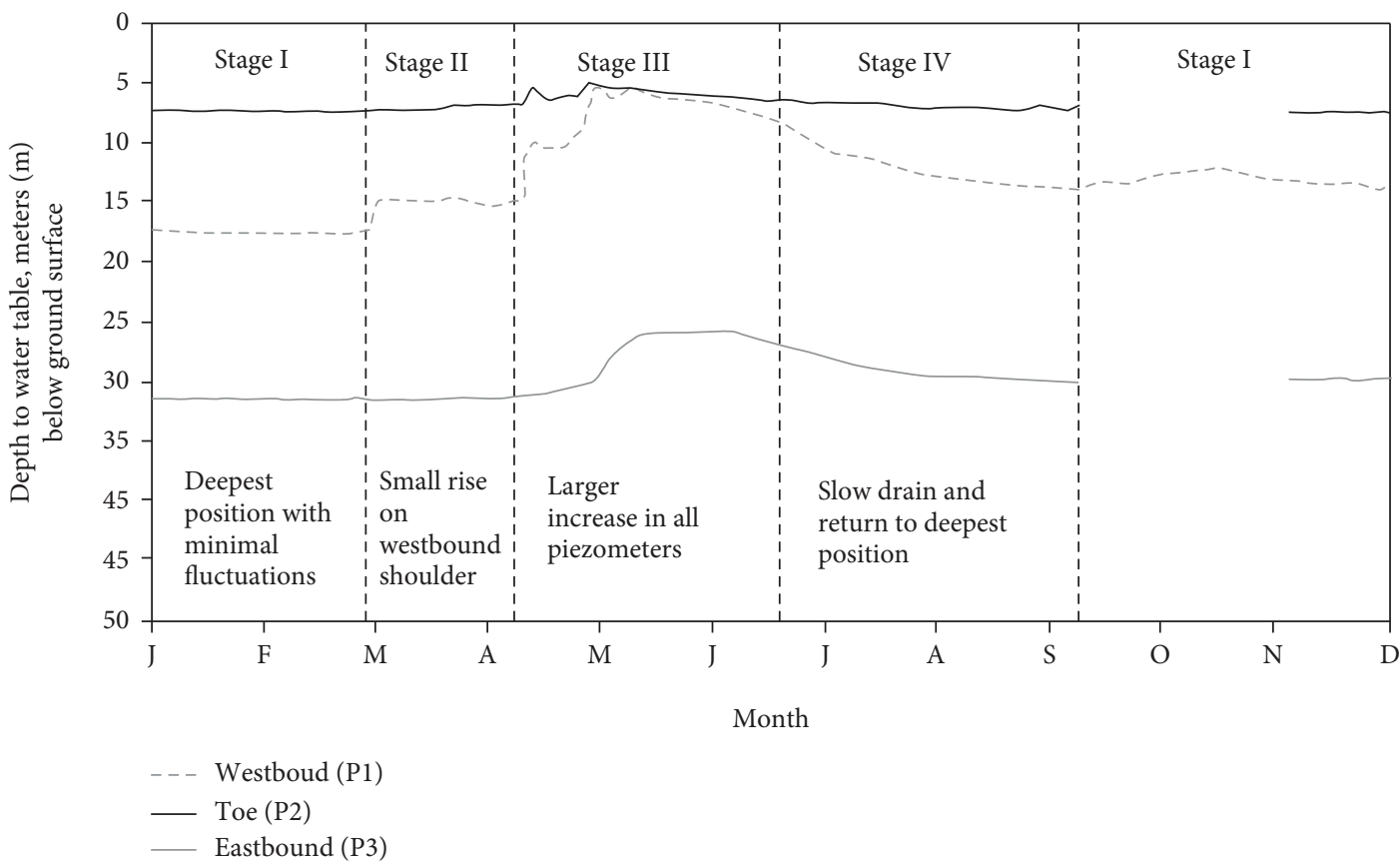

FIGURE 6: Water table variation for months in 2014 (January through December) showing four stages in conceptual model. Data was lost for P2 and P3 during the months of September and October.

the competent bedrock results in flow parallel to the bedrock interface [9]. In the northern part of the slope, the bedrock is steeply inclined, so large volumes of groundwater travel downslope swiftly. Once the fast-moving groundwater reaches the highway portion, two changes in the stratigraphy cause a backup of the groundwater flow: (1) the lower hydraulic conductivities of the fill and decomposed gneiss and (2) the shallower bedrock dip. Consequently, a significant rise in water table elevation occurs along the westbound shoulder while $30 \mathrm{~m}$ across the highway the water level increases by only half as much. Additionally, the response in the eastbound shoulder is delayed by as much as 30 days from the initial response in the westbound. Further downslope, near the toe, groundwater flow encounters native 


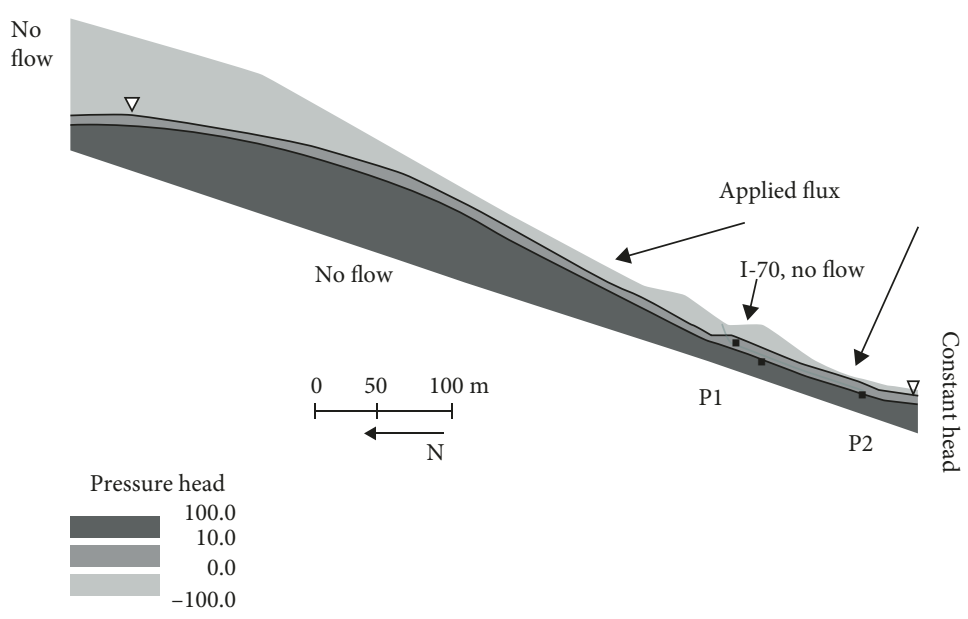

FIGURE 7: Numerical model domain: boundary conditions, initial conditions, and observation nodes.

colluvial and alluvial soils with higher hydraulic conductivities. The higher hydraulic conductivities, combined with the fact that the Straight Creek is about $90 \mathrm{~m}$ away, result in minimum fluctuations of the water table near the toe (Figure 5(c)).

Depending on the snow depth and temperature conditions, annual cumulative infiltration can range from $0.4 \mathrm{~m}$ to $1.2 \mathrm{~m}$; during most years, snowmelt contributes about $80 \%$ of the infiltration. Due to the large infiltration, the water table rises above the failure surface which results in the reduction of effective stress and shear strength of the soils. At this point, the embankment is likely at its least stable condition and the landslide is reactivated.

Stage IV. Fall: during late summer and fall, rainfall is the only contributor to infiltration and is minimal compared to the snowmelt in earlier months. The groundwater drains downslope generally at a slower rate than its previous rise; eventually, the water table reaches a steady state condition at a position below the failure surface. In drier years, this steady state condition can be reached in 3 months whereas it may take more than five months in wetter years (Figure 5(d)). Since pore water pressures decrease, effective stresses and shear strength increase and minimum displacements are expected.

Expected changes in slope stability in this conceptual model roughly coincide with inclinometer readings taken in 2008-2009 by the Colorado Department of Transportation [9] and with multiple anecdotal reports from CDOT personnel about paving that stretch of the highway.

\section{Numerical Model of the Site's Hydrological Behavior}

4.1. Setup of Numerical Model. The conceptual model indicates that the hydrological behavior of the site has a decisive effect on the stability of the slope. With the change in water content and pore water pressures, suction stress changes; consequently, effective stresses are affected, and therefore, the stability of the slope varies. In order to quantify these effects, a two-dimensional finite element numerical model that simulates the hydrology of the Straight Creek landslide was used based on the conceptual model to simulate the hydrological conditions of the site. The governing equation used for the transient unsaturated flow in the hillslope is Richards' equation [18]:

$$
\nabla \cdot K(h) \nabla H+W=\frac{\partial \theta(h)}{\partial t},
$$

where $K(h)$ is the hydraulic conductivity function (HFC), $H$ is the total head, $W$ is flux from a source or to a sink, and $\theta(h)$ is the soil water retention curve.

The numerical model was set up using the water flow module of the commercial software Hydrus-2D. Six hydrogeologic units comprise the domain which mimics the stratigraphy obtained during the field investigations and covers the area identified as the watershed contributing to the site (Figure 7). Hydrological and strength properties are reported in Table 1 and were obtained from laboratory testing, field measurements, and previous reports on the site. The numbers marked with a star were obtained as a part of the calibration of the numerical model. Initial conditions were reached by applying a constant infiltration of $0.001 \mathrm{~m} /$ day for several years so that a steady state was attained. The magnitude of the infiltration applied was chosen so that the resulting initial pressure head profile reflects the water table position observed in the field during the winter months (at its lowest position). A "no flow" boundary condition is applied on the north end to represent the extent of the watershed as no groundwater will enter or exit the system from this area; likewise, a "no flow" condition is also applied to the lower boundary of the domain, far enough into the bedrock to prohibit vertical seepage through the bedrock layer; a constant head boundary condition downslope (south side) so that the water table is held at $8 \mathrm{~m}$ bgs, representing the effects of Straight Creek about $90 \mathrm{~m}$ away from the toe of the slide; finally, variable flux is applied along the land surface with the exception of the highway portion which has a no flow boundary (Figure 7). 
Applied fluxes for the land surface boundary condition (Figure 7) are based on atmospheric and precipitation data from the Grizzly Peak SNOTEL station. SWE data from 2011 to 2015 are provided in Figure 4(c); snow accumulates during the winter months; in the beginning of the spring, there are some days when the temperature is warmer than freezing producing a decrease in the snowpack and therefore some infiltration into the slope. Precipitation in the model includes both snowfall and rainfall and is presented in Figure 4(b); any negative change in SWE is interpreted as snowpack melting and assumed to directly infiltrate, any increase in cumulative precipitation when SWE is zero and temperatures are above freezing is assumed to also directly infiltrate. Finally, observation nodes P1, P2, and P3 were placed at locations coinciding with the piezometers in the field.

The model was calibrated using the piezometer data from year 2013. The variables in Table 1 marked with a star were used as adjusting parameters to obtain the smallest difference between measured and modeled groundwater table elevations. Additionally, the qualitative behavior of annual changes in groundwater elevation for the locations at the three piezometers was taken into account. This process was iterative; initial estimates for the inverse modeled variables were obtained from the Hydrus-2D soils bank and hydrologic parameters of only one soil material at a time were inverse modeled. Even though hydraulic conductivity values had been measured in situ for the colluvium and highly fractured gneiss, these variables were also inverse modeled within a narrow range because hydraulic conductivity is very sensitive to effects of scale and disturbance. Once the model was calibrated, data from years 2014 and 2015 were used to validate it.

A comparison of the observed and simulated groundwater table fluctuations is presented in Figure 8(a). Solid lines represent the data measured in the field while the dotted lines plot the data obtained with the numerical model. There are two main differences between simulated and observed water levels: (1) a lag in time between the measured and simulated increase in water table level; this may be the result of the fact that the location of the Grizzly Peak station is more forested than the landslide site, causing the later to experience faster and earlier infiltration, and (2) in the beginning of the spring, the field data show an increase of about $2 \mathrm{~m}$ in the water level measured by the westbound shoulder before the other sensors detect a change. This may be due to the fact that snow on that stretch of the highway is plowed into the westbound shoulder, so that at the end of the winter there is a tall compacted ice/snow block. When the temperature warms up, more water infiltrates close to the westbound shoulder than in the rest of the slope.

It is evident that infiltration occurs earlier in the study site than in Grizzly Peak; for example, in 2015, the monitored groundwater table increases before any SWE negative changes were measured in Grizzly Peak. Adjusting the timing of the infiltration by applying it three weeks earlier leads to a better comparison between the observed and simulated groundwater responses (Figure 8(b)). The observed seasonal changes in water table position are reflected in the numerical simulation with a large rise in the westbound shoulder location (P1), followed by a smaller rise in the eastbound shoulder location (P3) and minimal change near the toe of the slope (P2). Simulated results mirror the observed ratio between the rise of the water table in westbound (P1) and eastbound (P3) locations each year, which is roughly $2: 1$. For example, in 2015, the water table increased about $9 \mathrm{~m}$ beneath the westbound shoulder while it only changed $4.3 \mathrm{~m}$ beneath the eastbound shoulder.

4.2. Numerical Model Results. Once calibrated, the numerical model was used to (1) investigate in more detail the infiltration process in the site using particle tracking and looking at pressure head profiles, (2) perform a parametric analysis to predict groundwater table location for a dry year (precipitation is lower than average) and for a wet year (precipitation is higher than average), and (3) perform a slope stability analysis for the 4 stages in the conceptual model for a year with average precipitation.

Flow pathways created by particle tracking at five locations on the surface north of the highway confirm the contribution of the watershed to the groundwater in the site (Figure 9). On the north side of the highway, water infiltrates into the slope through the highly fractured gneiss; subsequently, most of the water flows downslope parallel to the interface with the competent bedrock eventually discharging at the creek. Water that infiltrates at points located further than $300 \mathrm{~m}$ in horizontal distance from the highway flows into the competent bedrock layer, which has a significantly lower hydraulic conductivity. Additionally, when the soils near the surface have low initial moisture content, their hydraulic conductivity could be as low as $0.01 \mathrm{~m} /$ day slowing down the initial water infiltration.

Pressure head transects in the study area provide an insight on the groundwater table location with respect to the failure surface. As an example, pressure head distributions of the slide area for the year 2015 are provided in Figure 10. The modeled groundwater table is marked as the interface between the dark grey and the medium dark grey contours. For comparison, the measured water table locations are plotted with a thick red dotted line. In addition, a white dotted line illustrates the position of the slide's failure surface. During the winter season (Stage I), the simulated water table rests along the competent bedrock boundary, below the failure surface; thus, the soil above the water table has negative pressure heads that mostly range between $-5 \mathrm{~m}$ and $0 \mathrm{~m}$ although close to the surface there are areas with even lower pore water pressures. When the spring season begins (Stage II), water starts infiltrating into the hillslope and simulated pressure heads and moisture contents increase. The simulated water table underneath the westbound shoulder increases $\sim 0.9 \mathrm{~m}$ in elevation, which is smaller than the $\sim 2.5 \mathrm{~m}$ measured with the piezometer; this difference may be due to a combination of snow plowed into the westbound shoulder of the highway and working with precipitation data from Grizzly Peak which experiences later snowmelt infiltration than our site. In this stage, most of the 


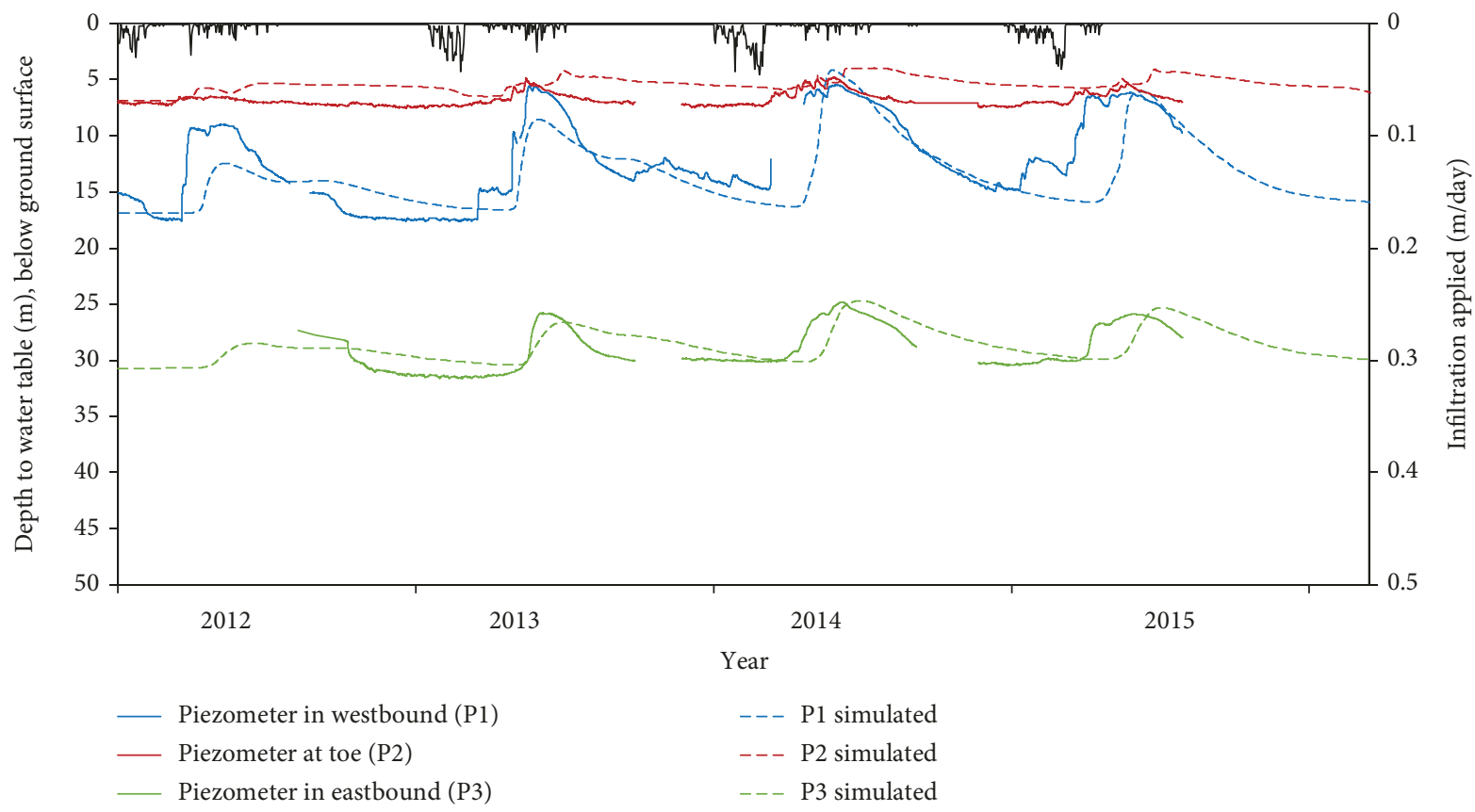

(a)

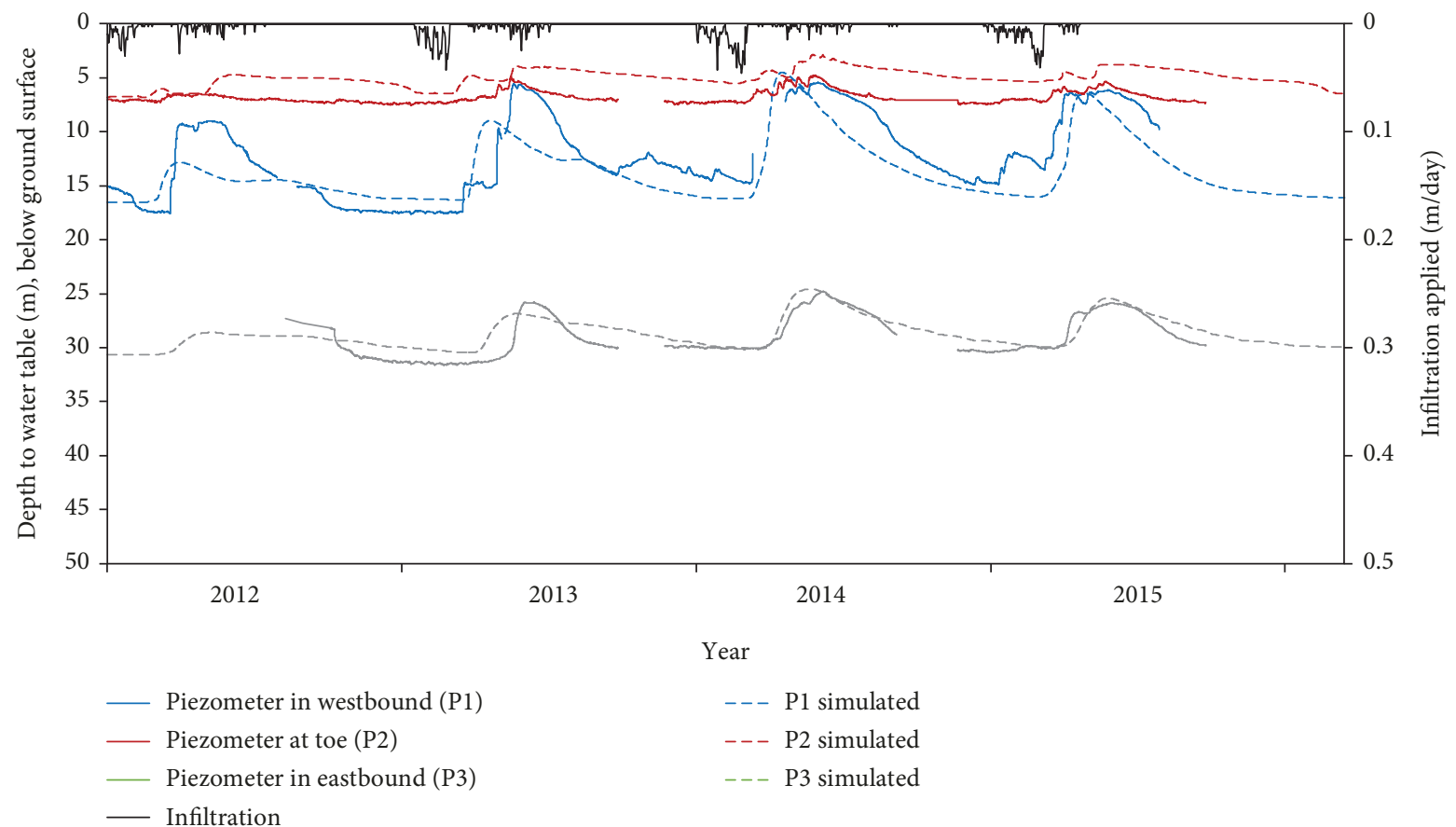

(b)

FIGURE 8: Comparison of groundwater table levels monitored in the field and simulated with numerical model: (a) with infiltration applied as reported at Grizzly Peak and (b) with infiltration applied three weeks earlier.

water infiltrating into the slope does not yet reach the water table, so aside from the area near the westbound shoulder, there are only small changes in the water table location. In the early summer (Stage III), the infiltration reaches the saturated zone and the simulated water table rises throughout the watershed. Both simulated results and measured data indicate a $9 \mathrm{~m}$ rise in the groundwater table underneath the westbound shoulder. Likewise, about $30 \mathrm{~m}$ across the highway, a $4.6 \mathrm{~m}$ rise is both modeled and measured underneath the eastbound shoulder. In the fall (Stage IV), infiltration rates decline and the simulation shows a decrease in pressure head and moisture content near the surface and a 


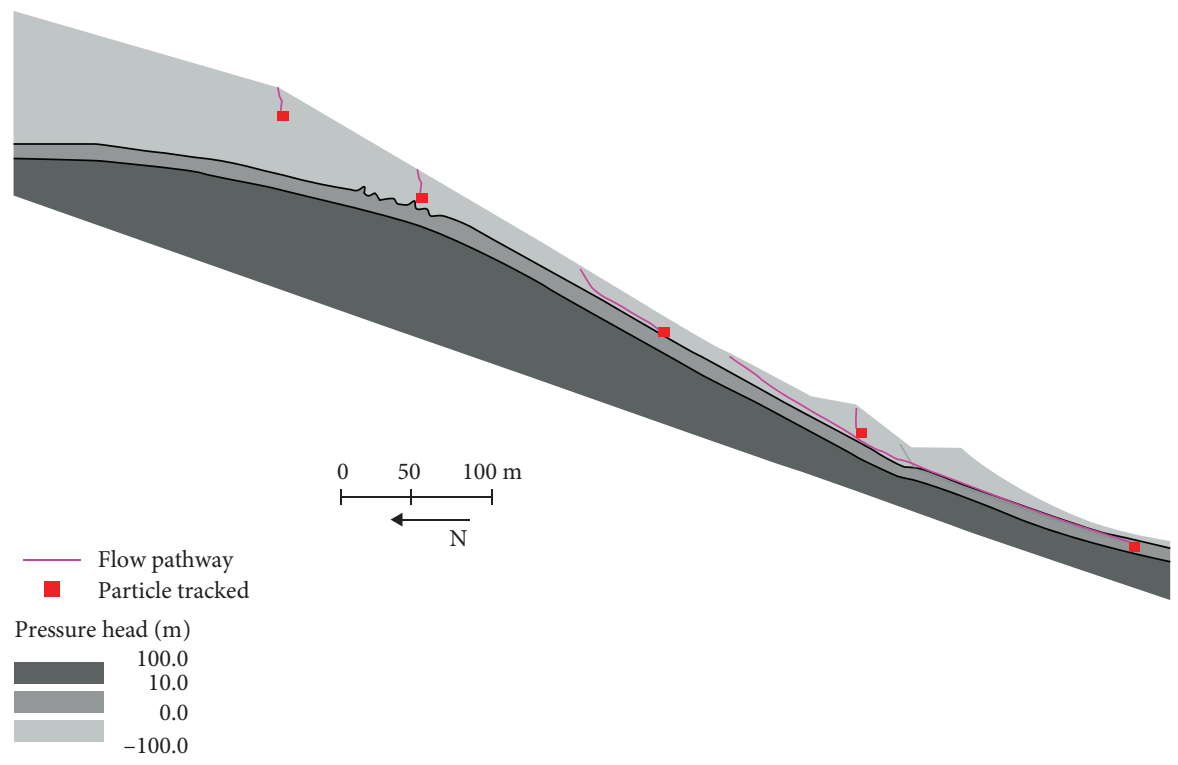

FIGURE 9: Flow pathways of one year created by particle tracking of five points in the slope north of I-70.

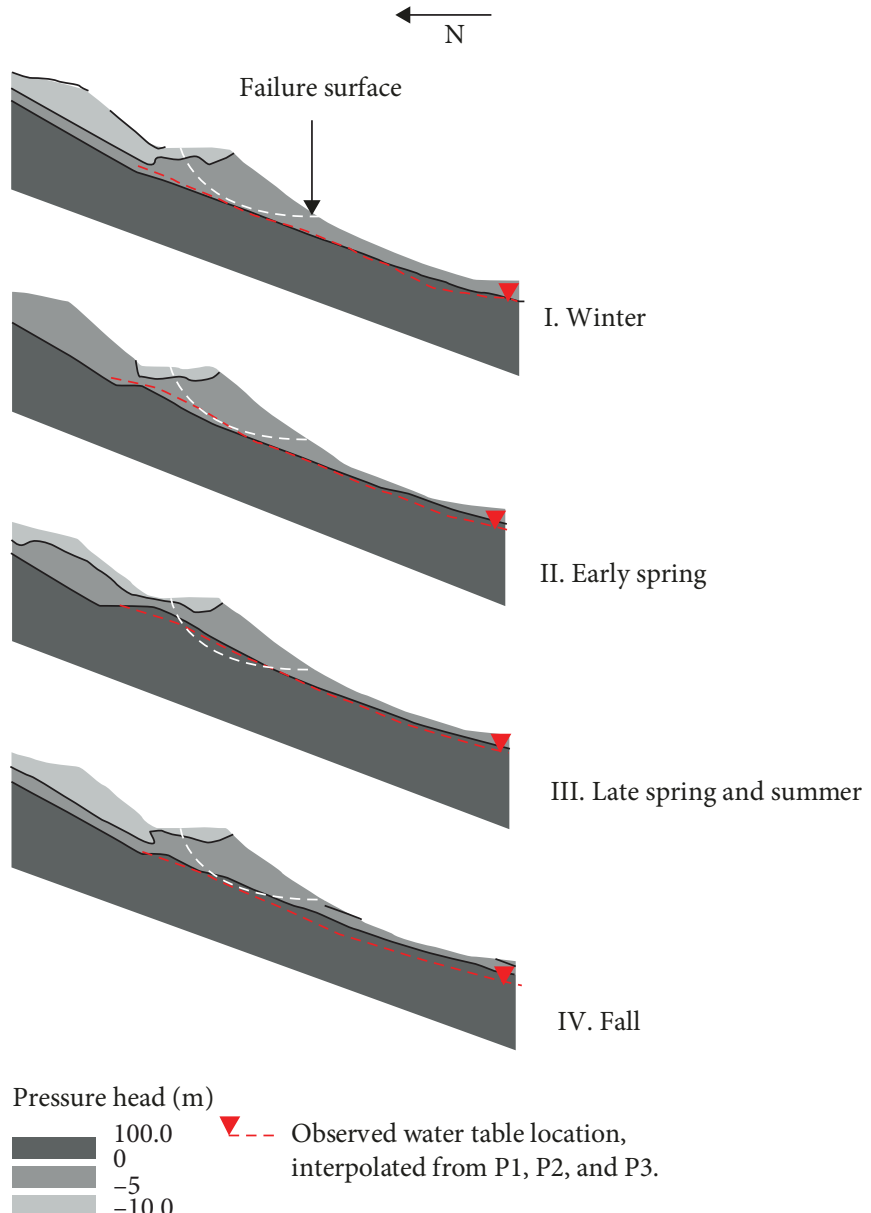

FIGURE 10: Simulated snapshots of pressure head transects near I-70 compared with measured water table during each conceptual model stage over the course of one average year. Winter transect taken at the lowest water table position, late spring and summer transect taken at peak values for water table position, and early spring and summer transect taken at average water table position values within the stage. 
lowering of the water table throughout the watershed. The simulated water table drains earlier in the westbound location than the water table recession observed in the field, whereas a slight delay in draining is seen in the simulation near the eastbound location. Once again, we attribute this delay between observed and simulated changes in water table level to assuming atmospheric conditions that are similar to the study site, but not always exact. The numerical model qualitatively describes the behavior of the water table near the toe, but the simulated results show an overall water table about $2 \mathrm{~m}$ shallower than the field observations. This difference may be due to having a constant head boundary for the southern extent of the modeled watershed instead of a changing head with time; however, not enough information for meaningful time varying boundary conditions is available.

We evaluated groundwater conditions for two scenarios: (1) a "dry year" with a cumulative infiltration of $0.49 \mathrm{~m}$, which is similar to 2002 and lower than the annual average of $0.58 \mathrm{~m}$, and (2) a "wet year" with cumulative infiltration of $1.10 \mathrm{~m}$, which is similar to 2011 and much larger than average. Both scenarios start with the same initial conditions. The changes in groundwater level at the locations of piezometers P1, P2, and P3 are provided in Figure 11; the thick lines plot data during a wet year while the thin dashed lines show variations during a dry year. In the winter season, the groundwater table is similar in both cases because no infiltration occurs during that time; however, the difference between annual minimum and maximum water table elevations between the wet and dry years is more than $100 \%$. Beneath the westbound shoulder (P1), the water table changes by as much as $10.7 \mathrm{~m}$ in the wet year while the change is only $4.7 \mathrm{~m}$ in the dry year. In both scenarios, the variation of the water table underneath the eastbound shoulder is about half as much as in the westbound, with $5.2 \mathrm{~m}$ in the wet year and $1.84 \mathrm{~m}$ in the dry year. Near the toe, the water table changes $1.4 \mathrm{~m}$ in the wet year and $0.47 \mathrm{~m}$ in the dry year.

\section{Slope Stability Analysis}

The stability of the site was analyzed using an extended Bishop's method of slices, accounting for the effect of suction stress in the soil. Using water contents and pore water pressures obtained from the numerical model results, suction stresses can be calculated using the closed-form equations proposed by Lu and Likos [19, 20]:

$$
\begin{aligned}
& \sigma^{S}=-\left(u_{a}-u_{w}\right), \quad u_{a}-u_{w} \leq 0, \\
& \sigma^{S}=-\left(u_{a}-u_{w}\right) S_{e}, \quad u_{a}-u_{w} \geq 0,
\end{aligned}
$$

where $\sigma^{S}$ is the suction stress that is a characteristic function of saturation or matric suction, $\left(u_{a}-u_{w}\right)$ is the matric suction, and $S_{e}$ is the equivalent degree of saturation. Effective stress for variably saturated porous materials is defined as [19]

$$
\sigma^{\prime}=\sigma-\left(u_{a}+\sigma^{S}\right) I
$$

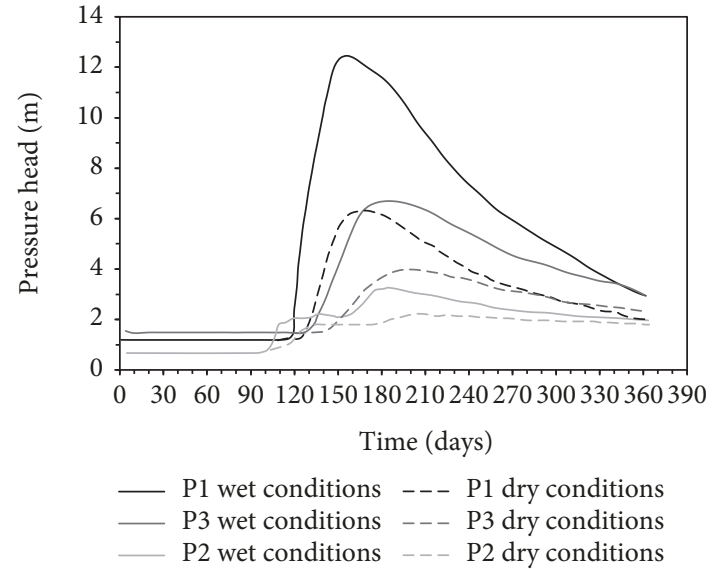

FIgure 11: Pressure head variation at P1, P2, and P3 for a dry year (cumulative infiltration of $0.49 \mathrm{~m}$ ) and a wet year (cumulative infiltration of $1.10 \mathrm{~m}$ ). Initial conditions taken at January 1.

where $\sigma$ is the total stress tensor, $I$ is the second-order identity tensor, and $u_{a}$ is the pore air pressure. The factor of safety using extended Bishop's method of slices was calculated using $\mathrm{Lu}$ and Godt [21] proposed equation:

$$
\begin{aligned}
\mathrm{FS}_{S} & =\sum_{n=1}^{m} \frac{\left(c^{\prime} b_{n}+W_{n} \tan \Phi^{\prime}-\sigma_{n}^{S} b_{n} \tan \Phi^{\prime}\right) /\left(I\left(a_{n}, \Phi^{\prime}, \mathrm{FS}_{S}\right)\right)}{\sum_{n=1}^{m} W_{n} \sin \alpha_{n}} \\
I & =\cos \alpha_{n}+\frac{\tan \Phi^{\prime}}{\mathrm{FS}_{S}} \sin \alpha_{n}
\end{aligned}
$$

where $c^{\prime}$ and $\phi^{\prime}$ are the effective cohesion and friction angle of the soil at the base of the slice, $b_{n}$ is the width of the slice, $W_{n}$ is the weight of the slice, and $\alpha_{n}$ is the angle of the slice with respect to the horizontal. A cross-sectional area with the sliding surface, material distribution, and slice discretization is provided in Figure 12. Four stability analyses corresponding to the groundwater table conditions in the four identified stages were performed. The results are consistent with the conceptual model; the factor of safety is larger in winter, when the water table is below the failure surface and suction stresses in the hillslope materials improve the stability of the embankment. As groundwater table rises, pore water pressures along the failure surface become positive and factor of safety decreases. During the beginning of summer, when the water table is at its peak, the factor of safety is smaller than 1, which signifies failure. During the rest of the year, the factor of safety ranges from 1.02 to 1.05 , and therefore, little or no displacement is expected.

\section{Summary and Conclusions}

Infiltration-induced landslides are common geological hazards in the world, and their occurrence results in costly damages that sometimes claim lives; many of these landslides are triggered by a change in the hydrological conditions. This 


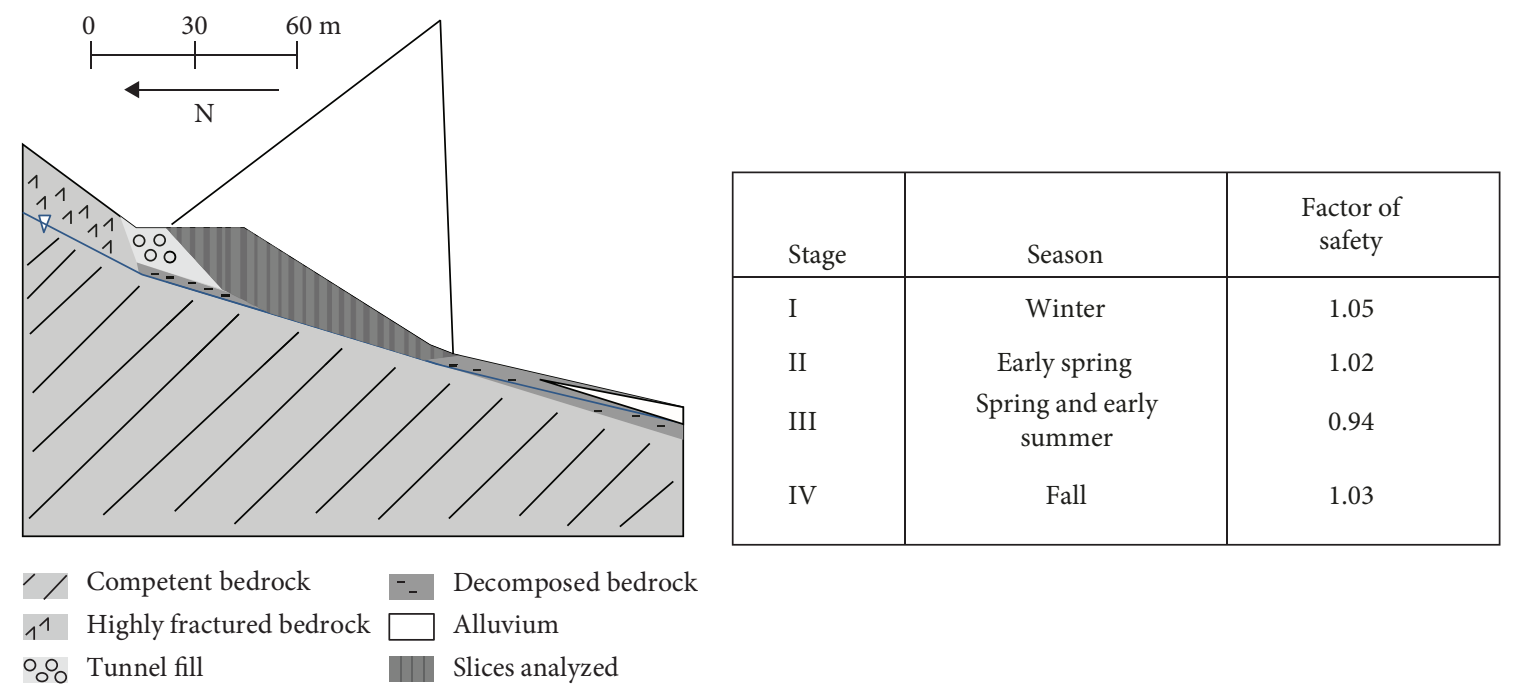

FIGURE 12: Stability analysis using modified Bishop's method that accounts for suction stress. Center and radius of failure circle displayed.

paper presents a study of the hydrological behavior and its effects on slope stability of a seasonally active landslide on an embankment on Interstate-70 west of the Eisenhower Tunnel. Records indicate that more than $0.6 \mathrm{~m}$ of vertical displacement were measured in the past four decades. In addition, previous studies on the site identified the main physical mechanisms in the slope and quantified the importance of understanding the hydrological behavior in the site. Thus, three piezometers were installed near the crest and the toe of the landslide and groundwater table was monitored every 30 minutes for three years. The difference between annual minimum and maximum water table levels beneath the westbound shoulder is twice as much as the annual difference beneath the eastbound shoulder, only $30 \mathrm{~m}$ apart. During an average year, the water table beneath the westbound shoulder can rise about $9 \mathrm{~m}$ whereas it can rise $30 \mathrm{~m}$ across the highway, the water table underneath the eastbound shoulder rises half as much (about $4.6 \mathrm{~m}$ ). The changes in water table level near the toe are smaller than $2 \mathrm{~m}$. The objective of this work is to characterize this hydrological setting by developing (1) a sound conceptual model that captures the principal mechanisms in the site and (2) a numerical model that can produce results similar to the field measurements. Once calibrated, the hydrological numerical model is used to investigate in more detail the infiltration process in the site, to perform a parametric analysis to predict groundwater table locations for precipitations lower and higher than average conditions, and to perform a seasonally varying stability analysis on the site. The following conclusions can be drawn from these analyses.

(1) Detailed characterization of the subsurface soil layers, stratigraphy, and atmospheric conditions is needed to accurately simulate transient changes in hydrological responses that drive seasonal variations in slope instability. These factors must be defined throughout the entire watershed, not only the immediate landslide area but also the upslope area where groundwater recharge takes place, to fully understand the hydrological conditions of the immediate landslide site

(2) The large difference in water table position cross a relatively small distance is due to a combination of three factors: (a) the large size of the watershed that allows a significant amount of infiltration into the uphill slope area, (b) the contrast of hydrological properties of soils in the watershed, especially saturated hydraulic conductivities around the area immediately beneath the highway, and (c) the changes in the steepness of the competent bedrock as it transitions from the northern slopes to the area underneath the highway. These factors control the direction, flux, and amount of excess groundwater flow traveling through the slope

(3) The numerical modeling results indicate that the difference between minimum and peak water table levels in the site can vary by more than a $100 \%$ depending on the seasonal hydrologic conditions. In both, a wet and a dry year, the larger changes occur underneath the westbound shoulder; in a dry year, the water table varies by $\sim 4.7 \mathrm{~m}$ whereas in a wet year it can rise up to $10.7 \mathrm{~m}$

(4) Pore water pressures near the failure surface change from negative in winter to positive in the beginning of the summer; consequently, suction stresses and therefore the factor of safety vary throughout the year. Using extended Bishop's method of slices for variably saturated soil, the factor of safety varies from 1.02 to 1.05 in winter, early spring, and fall but reduces to 0.939 (which indicates failure) in the beginning of the summer

(5) The numerical modeling results indicate that future remediation options should focus on minimizing the large water table rise north of I-70 


\section{Data Availability}

The data used to support the findings of this study are included within the article.

\section{Disclosure}

The field characterization portion of this study was presented in the Eighth International Conference on Case Histories in Geotechnical Engineering Congress, Philadelphia, PA.

\section{Conflicts of Interest}

The authors declare that they have no conflicts of interest.

\section{Acknowledgments}

This study is supported by a grant (CDOT\#430060) from the Colorado Department of Transportation to AW and NL. In-kind support for partial field instrumentation from the Geologic Hazards Science Center of the U.S. Geological Survey is greatly appreciated. Some of the site characterization was performed by Michael Morse.

\section{References}

[1] N. Casagli, S. Dapporto, M. Ibsen, V. Tofani, and P. Vannocci, "Analysis of the landslide triggering mechanism during the storm of 20th-21st November 2000, in Northern Tuscany," Landslides, vol. 3, no. 1, pp. 13-21, 2005.

[2] G. B. Crosta and P. Frattini, "Distributed modelling of shallow landslides triggered by intense rainfall," Natural Hazards and Earth System Sciences, vol. 3, no. 1-2, pp. 81-93, 2003.

[3] R. M. Iverson, "Landslide triggering by rain infiltration," Water Resources Research, vol. 36, no. 7, pp. 1897-1910, 2000.

[4] H. Rahardjo, X. W. Li, D. G. Toll, and E. C. Leong, "The effect of antecedent rainfall on slope stability," Geotechnical \& Geological Engineering, vol. 19, no. 3-4, pp. 371-399, 2001.

[5] T. Tsai, H. Chen, and J. Yang, "Numerical modeling of rainstorm-induced shallow landslides in saturated and unsaturated soils," Environmental Geology, vol. 55, no. 6, pp. 12691277, 2008.

[6] R. I. Borja and J. A. White, "Continuum deformation and stability analyses of a steep hillside slope under rainfall infiltration," Acta Geotechnica, vol. 5, no. 1, pp. 1-14, 2010.

[7] D. V. Griffiths and N. Lu, "Unsaturated slope stability analysis with steady infiltration or evaporation using elasto-plastic finite elements," International Journal for Numerical and Analytical Methods in Geomechanics, vol. 29, no. 3, pp. 249-267, 2005.

[8] N. Lu and J. W. Godt, "Infinite slope stability under unsaturated seepage conditions," Water Resources Research, vol. 44, article W11404, 2008.

[9] N. Lu, A. Wayllace, and S. Oh, "Infiltration-induced seasonally reactivated instability of a highway embankment near the Eisenhower Tunnel, Colorado, USA," Engineering Geology, vol. 162, pp. 22-32, 2013.

[10] F. Vahedifard, D. Leshchinsky, K. Mortezaei, and N. Lu, "Effective stress-based limit-equilibrium analysis for homogeneous unsaturated slopes," International Journal of Geomechanics, vol. 16, no. 6, article D4016003, 2016.
[11] A. Wayllace, N. Lu, S. Oh, and D. Thomas, "Perennial infiltration-induced instability of Interstate 70 embankment west of the Eisenhower/Johnson Memorial Tunnels," in GeoCongress 2012: State of the Art and Practice in Geotechnical Engineering, pp. 497-506, Oakland, CA, USA, March 2012.

[12] T. S. Lovering, Geology and Ore Deposits of the Montezuma Quadrangle, vol. 178, US Govt. Print. Off, Colorado, 1935.

[13] Robinson \& Associates, The Geologic Investigation of the Straight Creek Landslides, Colorado Department of Highways, Denver, CO, USA, 1971.

[14] B. Thunder, The Hydromechanical Analysis of an InfiltrationInduced Landslide Along I-70 in Summit County, CO, [M.S. Thesis], Colorado School of Mines, Golden, CO, USA, 2016.

[15] A. Wayllace and N. Lu, "A transient water release and imbibitions method for rapidly measuring wetting and drying soil water retention and hydraulic conductivity functions," Geotechnical Testing Journal, vol. 35, no. 1, pp. 103-117, 2012.

[16] M. T. van Genuchten, "A closed form equation for predicting the hydraulic conductivity of unsaturated soils," Soil Science Society of American Journal, vol. 44, no. 5, pp. 892-898, 1980.

[17] Y. Mualem, "A new model for predicting the hydraulic conductivity of unsaturated porous media," Water Resources Research, vol. 12, no. 3, pp. 513-522, 1976.

[18] L. A. Richards, "Capillary conduction of liquids through porous mediums," Journal of Applied Physics, vol. 1, no. 5, pp. 318-333, 1931.

[19] N. Lu and W. J. Likos, Unsaturated Soil Mechanics, John Wiley and Sons, New York, NY, USA, 2004.

[20] N. Lu and W. J. Likos, "Suction stress characteristic curve for unsaturated soil," Journal of Geotechnical and Geoenvironmental Engineering, vol. 132, no. 2, pp. 131-142, 2006.

[21] N. Lu and J. Godt, Hillslope Hydrology and Stability, John Wiley and Sons, New York, NY, USA, 2012. 

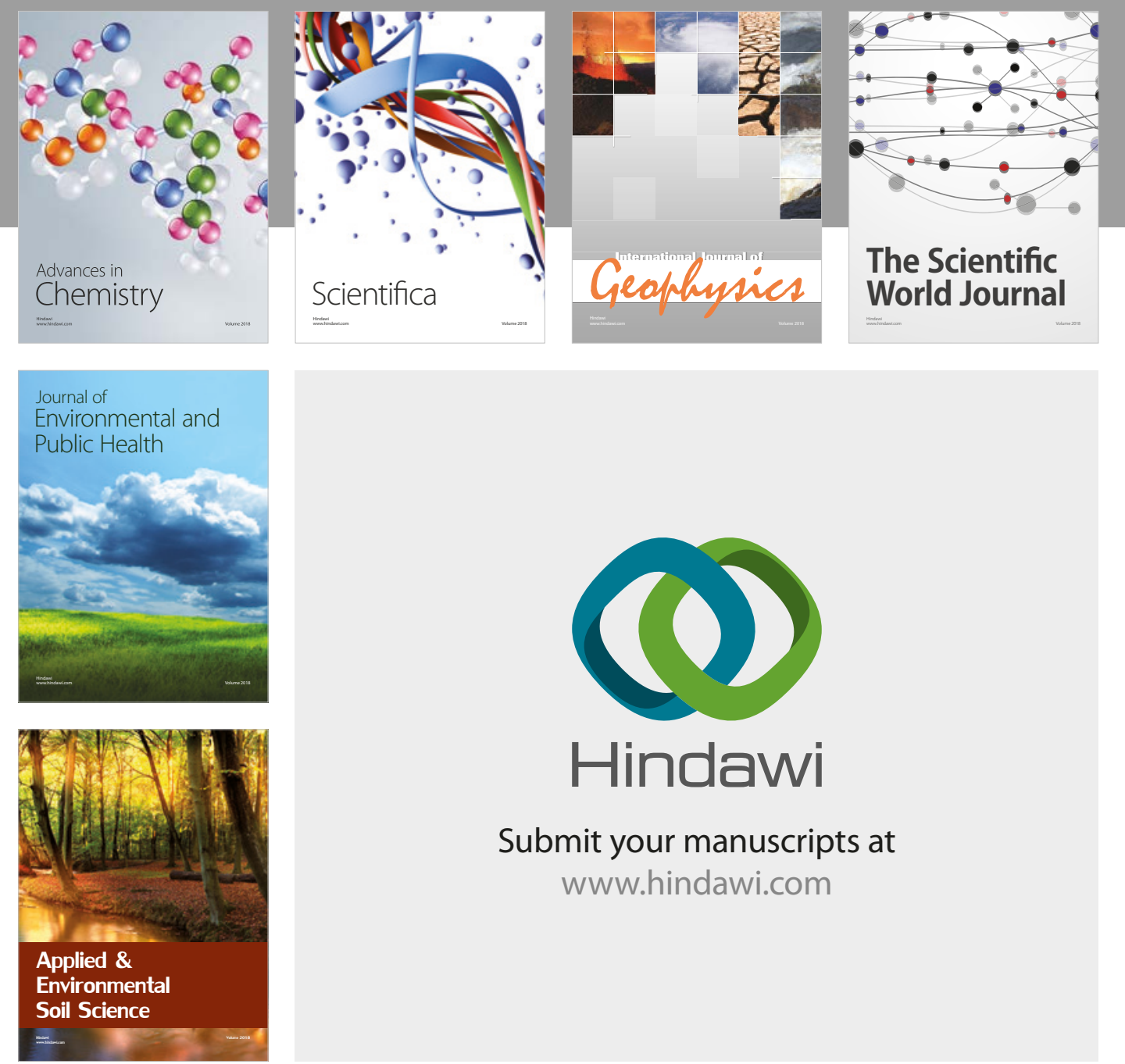

The Scientific

\section{World Journal}
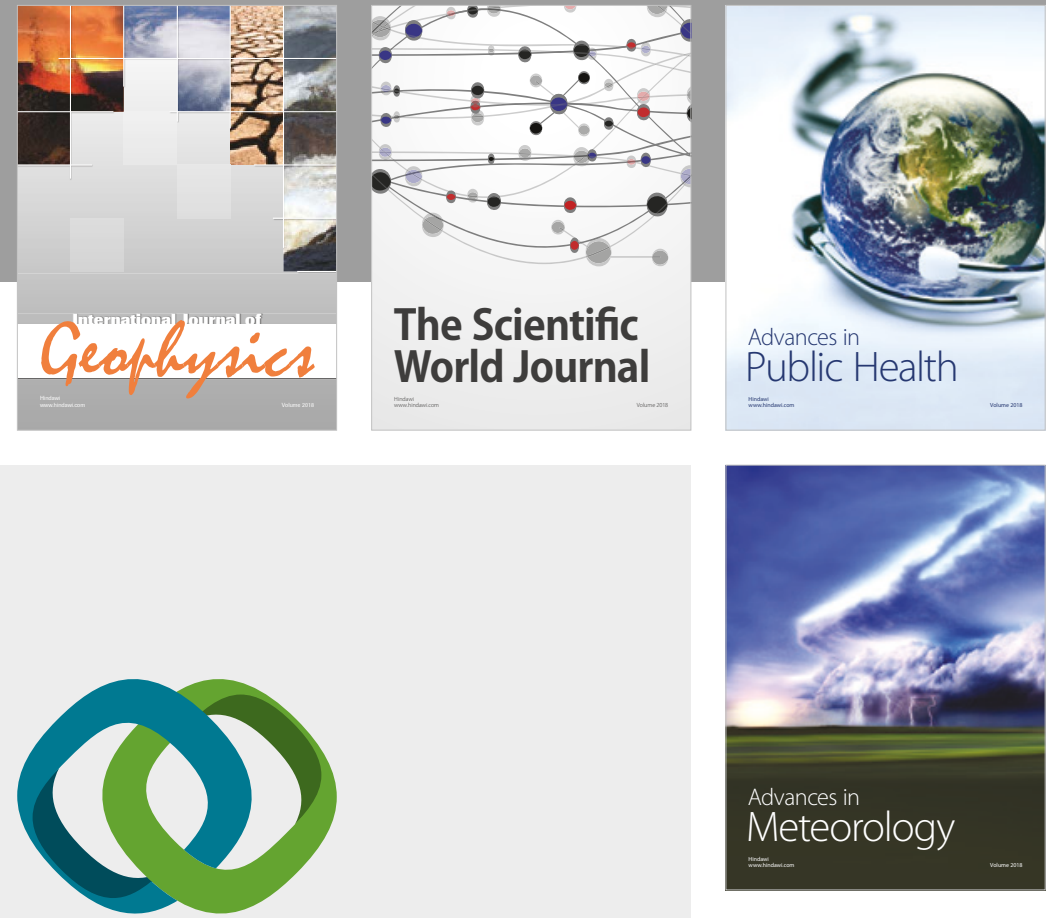

Advan

Public Health

\section{Hindawi}

Submit your manuscripts at

www.hindawi.com
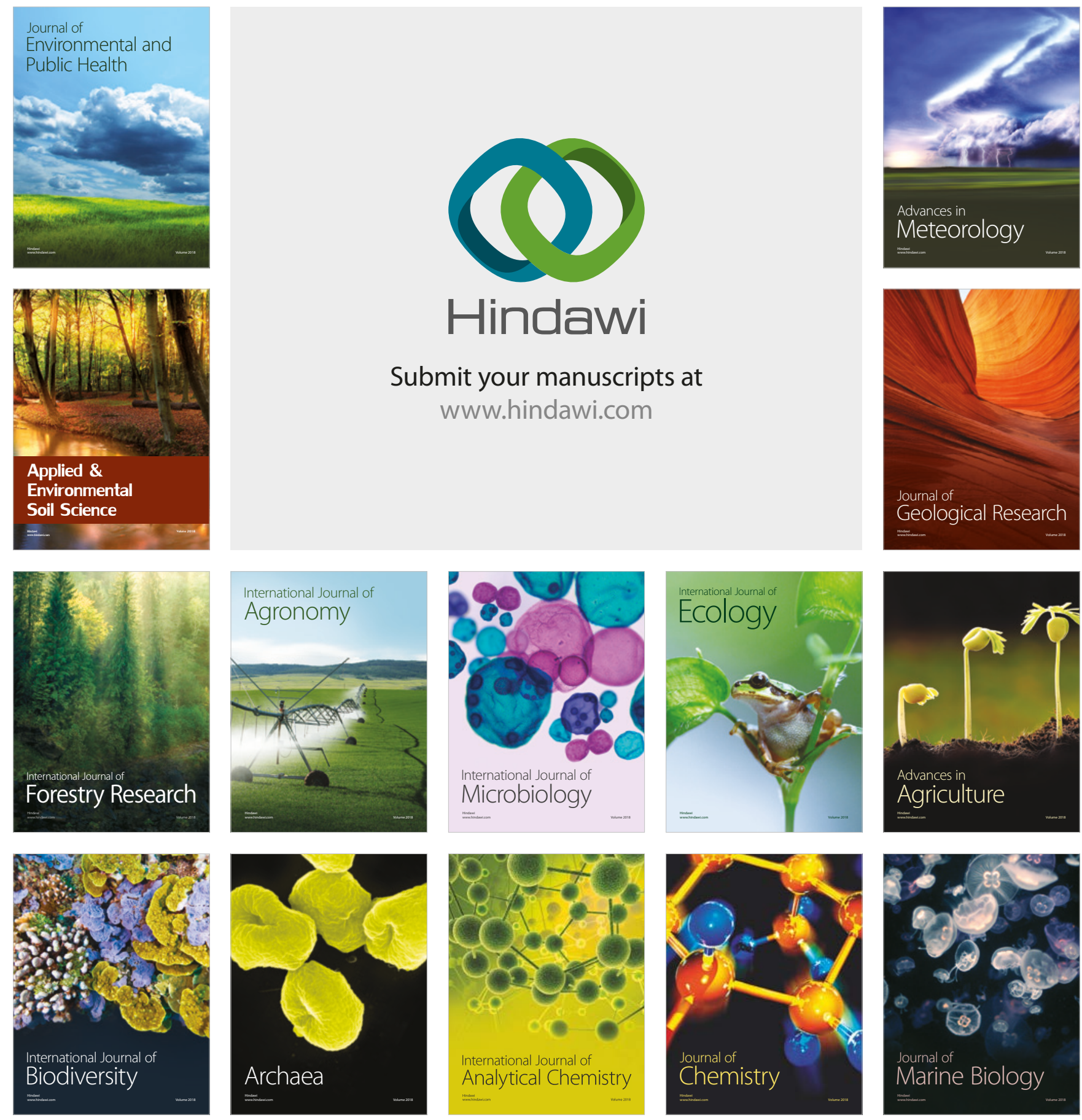